\title{
THE POTENTIAL CONTRIBUTION OF CHILDREN'S LITERATURE TO MULTILINGUALISM AND MULTICULTURALISM
}

\author{
Christiane Bimberg \\ University of Dortmund
}

After more than four decades, children's literature and its criticism and theory finally seem to be coming into their own on the international scene. That the establishment of children's literature as an academic discipline and field of studies of its own will not be easy is demonstrated by a number of difficulties and debates accompanying the process on administrative, scholarly, commercial and other levels. Children's literature has been part of the traditional battleground between literary studies and pedagogics/education in the past, but there is an urgent need now to bridge this divide in the interests of young readers. The literary-aesthetic potential of children's literature as an agent of education in multilingualism and multiculturalism is just one example of the contribution children's literature could make.

Dit blyk dat jeugliteratuur (die teorie daarvan en kritiek daarop) se stryd om erkenning op internasionale vlak na meer as vier dekades beloon word. Dat dit moeilik is om jeugliteratuur te vestig as $n$ akademiese vakterrein, word gedemonstreer deur ' $n$ aantal hakplekke en debatte wat die proses op administratiewe, wetenskaplike, ekonomiese en ander vlakke as hindernisse teëwerk. Kinder(jeug-) literatuur is lank reeds deel van die debat tussen letterkunde en pedagogiek/opvoedkunde, maar dit word nou dringend noodsaaklik om hierdie verskille te oorbrug - in die belang van jong lesers. ' $n$ Goeie voorbeeld van die bydrae wat jeugliteratuur kan maak, is die inherent literêr-estetiese potensiaal om 'n vennoot te wees in die opvoedingsproses, veral op die terreine van veeltaligheid en multikulturaliteit.

\section{THE TANGENTIAL POSITION OF CHILDREN'S LITERATURE}

There are a number of obstacles which prevent children's literature from assuming a more influential position in education. Two of these obstacles are the wide-spread prejudices and misconceptions about children's literature. This explains its still largely marginalised role at universities, even in Departments of English (Hunt, 1995: 19-31; Petzold, 1997: 75ff.). Children's literature as a discipline is also seriously hampered by the fact that, with few exceptions, texts are produced and chosen by adults for children and, consequently, highly subject to various societal and individual mechanisms of censorship (Bimberg, 1996: 40610).

\section{THE INTRICACIES OF CHILDREN'S LITERATURE}

Even within the ranks of those who see the study of children's literature as an academic discipline, there is not yet general agreement on how to delineate the field. I would argue that the nature of the debates in this area are an important constraining factor on the development 
of the discipline. Once we have accepted that children's literature is a cultural and ideological construct it is possible to explore some of the problems. In that light, two views of children's literature must be noticed and explored before we proceed.

(1) Children's literature may be viewed as a 'debased form of an adult text' (Hunt, 1994: 4).

The texts reflect demands made by adults on the thinking and behaviour of children (Hunt, 1994: 5; Lesnik-Oberstein, 1994: 26). Children's literature thus directly or indirectly contains adult notions of social norms, adult attitudes towards other cultures, towards the behaviour of the sexes etc. and therefore is 'an ideological minefield' (Hunt, 1994: 186). These texts inherently convey adult notions of good/desirable/useful books for children and young adults. Views of specialists tend to be polarised on this issue. Nor is it easy to gather reliable empirical data on children's responses as a means of arriving at a more complete picture. At present, criteria for a 'good' children's book are neither homogeneous nor historically stable or invariable.

(2) Children's literature does not conform to the strictures of the classical canon (Hunt, 1994: 6) because its texts do not (always) comply with patriarchal literary, cultural or social norms (e.g. Lewis Carroll).

\section{IMPLICATIONS FOR A MODERN STUDY OF CHILDREN'S LITERATURE}

In order to create an appropriate theory of children's literature or to develop principles for its criticism that take account of current practice, it is necessary to take a different and more complex approach to texts than has generally been done thus far. Drawing on arguments presented in the literature, I shall list the areas in which change will have to take place.

(1) It will be necessary to abandon the attitude that children's literature is inferior to adult literature or even of no importance.

(2) It is essential that children's books should be regarded outside the literary hierarchy, i.e. as an important 'system' of their own (Hunt, 1994: 7), but at the same time as having interrelationships with adult or general literature and culture.

(3) It is time to apply a broader definition of children's literature that comprises not only the literature written especially for children, but also that read by children (Hunt, 1994: 4).

(4) Children's literature has to be seen as a 'complex cultural phenomenon' (Gaschke, 1995: Vorwort -translated), which reflects child and adult interests (Hunt, 1994: 8) and operates on dual or even multiple levels.

(5) Child and childhood have to be recognised as cultural-ideological constructs in children's literature texts and treated as such. They also have to be viewed in the light of recent research on the 'real' child (Lesnik-Oberstein, 1994: 29).

(6) Contemporary theory on children's literature must be as complex and varied as the factors involved in the making of this literature (Bimberg, 1996).

(7) The applicability of adult or general literary criticism and theory to children's literature has to be subjected to critical reflection.

(8) An important first step, perhaps, would be to rewrite the history of children's literature (cf. Hunt, 1994: 27-36) in the light of contemporary research. 


\section{RECENT CHANGES IN CRITICAL STUDIES ON CHILDREN'S LITERATURE}

Although children's literature has the potential to provide valuable opportunities for young people to gain new perspectives, a number of factors constrain its role. However, there are new developments. A major change can be seen in the emergence of children's literature as an object of literary studies instead of pedagogic/educational studies (cf. Nikolajeva, 1996: 3, 5). Truly comparative or intercultural children's literature studies are also emerging (cf. Hurrelmann\& Richter, 1998: 7).

\section{1 Reasons}

A number of parallel and sometimes unrelated developments have encouraged the emergence of more and better qualified criticism on children's literature:

- The awareness that children's literature is worth reading, and so is worth writing about

- The development of criticism and theory in general into an academic industry

- The critical test of the applicability of the tools of adult or general literary criticism and theory to children's literature studies

- A weakening of the status of the literary canon

- The fact that the academic study of texts is at a crossroads, which gives to children's literature studies a trailblazing role

- The recent trend for children's literature to be studied across the old disciplinary divides of literary scholars and educationalists

- The emulation of other academic disciplines by children's book studies for tactical reasons (Hunt, 1994: 16-19)

- The (international) institutionalisation of children's literature studies

- A significant increase in academic debates on the subject

- The impact on the market of theoretical literature (e.g. in the publishing houses of Bloomsbury and Routledge)

- The publication not just of 'specialist studies', but an increase of books applicable in the academic teaching of literature (O'Sullivan, 1995: 95-96)

\section{2 Problems}

Several external and internal problems remain within critical study of children's literature. Critical theory for example,

partly denies the existence of a genre 'writing for children' by insisting that a good children's book is a good book 'in its own right', and partly demands that good writing for children, such as it is, should not too obviously appear to be for children.

(Hunt, 1994: 187)

There are some even greater hindrances. The criticism of children's literature still abounds with sentimentality about children's books and childhood (Hunt, 1994: 18; Bimberg, 1996: 406). Everyone feels that he/she has something to say about children's literature (children's literature as a "truly democratic phenomenon"; Hunt, 1994: 18). There is also a danger that futile academic disputes will be repeated. On the other hand there is an urgent need to draw together the very diverse critical approaches and to communicate outside and beyond 
academic specialisation (cf. Hunt, 1994: 16-18, 20). Last but not least the opposition between emotional involvement and rational distance in children's literature criticism, though not a phenomenon totally alien to adult or general literary criticism, needs to be dealt with in a methodologically responsible way.

\section{3 New insights}

Research has been done in a number of areas in the last decade:

(a) The role of children's literature in developing the skill of learning to read (e.g. cultural literacy: May, 1995: viii, ix,5)

(b) The need to represent cultural diversity in children's literature (May, 1995: 138ff.)

(c) Attitudes to reading and the characteristics of the reading process in child readers (May, 1995: viii, 4,14, 15, 17, 158-60)

(d) Ways of individualising teaching needs (May, 1995: 16)

(e) The correlation between literary criticism and teaching (May, 1995: 17, 18, 23, 188)

(f) The influence of literary theory on education's attitudes about children's literature (May, 1995: 23)

(g) The impact of education's attitudes on publishing politics and the creative practice (May, 1995: 122ff.)

(h) What criticism is about, how it works, what it is meant for, where its limitations are (May, 1995: 33; Lesnik-Oberstein, 1994: 3-6, 10, 13, 14, 25, 28, 29; Briggs, 1988: 372)

(i) The applicability of adult literary theory to children's literature (Lesnik-Oberstein, 1994: 133, 134, 140, 142, 164, 171, 174; May, 1995: vii, 16, 22, 161, 165, 167; Gaschke, 1995: 200, 202)

Current trends in children's literature criticism focus on studies defining children's literature, studies on children and childhood, cultural studies, ideology-centred studies, linguistics and stylistics, reader-response, psychoanalytical and feminist criticism, studies on intertextuality and studies investigating illustration and picture books (Hunt, 1996: 15-137; O'Sullivan, 1995: 96-109; Flynn, 1997: 143ff.; Nikolajeva, 1996: 8/9; Kuhlman / Lickteig, 1999: 93ff.)

\section{THE ROLE AND IMPORTANCE OF CHILDREN'S LITERATURE}

Children's literature has the potential to create its own paradigm of literature and literary scholarship. Children's literature:

(1) is 'one of the roots of western culture' (Hunt, 1994: 1), which is closely associated with the general literature and culture

(2) is important in educational, social and commercial terms (Hunt, 1994: 1)

(3) is neither neutral, trivial nor innocent, but a 'powerful literature' (Hunt, 1994: 3)

(4) is, due to the varied processes of its production, interdisciplinary par excellence (Bimberg, 1996: 406)

(5) is of obvious importance for an understanding of children and childhood

(6) often occasions the very first encounter with a foreign culture (also through translations) and can thus arouse an interest in foreign languages and an engagement with foreign cultures

(7) trains the imaginative and intellectual faculties of child readers and contributes to their linguistic and aesthetic skills (Bimberg, 1997) 
(8) becomes, in the age of the prevalence of the electronic media, a very special instrument for active reception and the development of imagination in child readers

(9) helps, by exposing young people at an early age to intellectual challenges, to train them step by step to become critical and life-long readers, and thus offers points of reflection on the correlation between theory/criticism and creative practice

(10) contains complex, many-levelled and ambivalent relations between author and reader, children and adults and therefore contributes to a more precise and complex definition of the correlation between 'child' or 'childhood' and 'adult' (cf. also Lesnik-Oberstein, 1994: 27)

\section{THE POTENTIAL CONTRIBUTION OF CHILDREN'S LITERATURE TO MULTILINGUALISM AND MULTICULTURALISM}

There are few countries, if any, where there are established programmes which allow young people to explore the value of multilingualism and multiculturalism critically. Jagoda Illner and Eike Thürmann have recently provided a critical review of the deficiencies of the current situation in Germany (1999: 10-12). Yet very often the first contact for children with a foreign culture occurs through the medium of a book from a foreign culture. At an early age this tends to happen in the form of reading a translation of this book. This may create further interest in other or more books by this author or other authors about this time or region or culture and other cultures, for instance. Later a book or books read in translation may be read in the original language. In that sense children's literature is a very appropriate way to introduce multilingualism and multiculturalism during the formative years of childhood and adolescence.

It is important to highlight some of the difficulties which prevent confident steps being taken towards establishing educational programmes.

\subsection{General problems}

(1) There is not yet hard evidence of the power of books or the reading process to encourage new attitudes or free people of prejudice.

(2) Many teachers come into the profession with rather limited knowledge or interest in children's literature: Based on her research in America, Jill P. May (1995: 5) warns that there may be tremendous deficits in reading attitudes and behaviour in the future. Most of her undergraduate students confessed not to have been readers in their youth. Most of them claim that their love of children was what had drawn them to teaching. A desire to pass on their love of reading was markedly absent.

At present there is an urgent need to improve in-service training. In, 1996 a thesis in Germany explored the findings of an inquiry made in 1988 into the current situation of children's literature as an object of school reading (cf. Oskamp, 1996: 57, 59, 64, $72,146)$. The thesis recommends that teachers should gain a more differentiated impression of the variety of children's literature and develop the ability to make meaningful selections from it. Particular emphasis was laid on the readability of the texts and the importance of the illustrations. Lessons at schools should include free reading offers, introductions to and presentations of books, meetings with authors, 
reading for pleasure periods in class or libraries (Oskamp, 1996: 146-59, 171; cf. also Rank, 1997: 190-91).

Curriculum design and course organisation at the universities and colleges should not be constrained by the expectations of students. May (1995) has noted that future teachers among her undergraduate students join children's literature courses largely because they are required. They often come along with wrong expectations and attitudes. Nobody in fact expects a course with a focus on critical thinking, individual analysis, and divergent literary interpretations, and nobody is looking for difficult reading. May argues that university courses that explore ideas about language and literature while they expand the undergraduate's repertoire of children's literature and understanding of literary criticism do valuable work (May, 1995: 6-8).

(5) Particular methodologies should be employed in children's literature courses.

May (1995) has drawn valuable conclusions from her extensive work with undergraduate students. Her preferred approach in course work is based on a mixture of research, self-reflection, and personal interpretation. She has come to the conclusion that the study of children's literature in college courses should deal with the books themselves as well as contemporary literary criticism. Although diverse approaches to children's literature should be allowed for, it is essential that adult readers develop a critical reserve and not look at children's literature as a romanticised picture of reality (May, 1995: 9, 10, 12, 13, 33).

(6) Within schools, the choice of texts may dissuade children from becoming readers.

On the basis of particular ideological and educational arguments, initial approaches to reading often favour the use of a reading scheme. These books are more concerned with developing the mechanics of reading and are less likely than 'real books' to encourage voluntary reading. Supporters of the 'real books' option are concerned with 'literacy' and at that with moving beyond 'functional literacy" (Hunt, 1994: 173). It is essential that the selection of texts used includes intellectually challenging and aesthetically complex texts as well as fantasy (Bimberg, 1997; May, 1995: 88ff.):

Youngsters who are growing up in a visual world of nightly news and horror films will find children's literature less engrossing than other media if they are continually introduced to simplistic stories, and they will not become lifelong readers.

(May, 1995: 10)

\subsection{Specific problems in the encounter of foreign cultures through children's books}

I believe that there are still a number of fundamental obstacles to multilingualism and multiculturalism at present, for instance, the lack of tolerance and openness even within one's own culture, not to mention that towards other cultures; the lack of tolerance in societal reality, not to mention literature; and multiculturalism without multilingualism. These issues, though important, lie outside the scope of this article. Of more immediate relevance, some of the matters which stand in the way of a move towards multilingualism and particularly multiculturalism are:

(1) An uneven international transfer of children's literature 
Emer O'Sullivan (1997) has pinpointed the contradiction within the frequently expressed idealist notions of children's literature as transgressing the borders and the real conditions for production and transfer in the international scale. She criticises the mythologised conception of a world literature for children and the ensuing fiction of an open world-wide exchange. Her research shows that the international transfer of children's literature is highly uneven and is characterised by cultural prejudices. This is evident in

(a) the low number of translations available in Great Britain and the US and the lack of interest in other cultures which that fact points to

(b) the internationalisation of children's culture (and the ensuing levelling of hitherto diverse cultures, implying a lack of curiosity and tolerance)

(c) the tight connection of the international market of children's literature with other media (O'Sullivan, 1997: 96, 99, 101)

(2) The national boundaries of children's literature (the cultural translatability of foreign literature)

Maria Nikolajeva (1996), the prominent Swedish critic of Russian origin, examines possible barriers and boundaries of national literatures (language, country, cultural community), in Chapter 1 of her influential study. She discusses the different forms for the interaction of national literatures in semiotic terms (Nikolajeva, 1996: 9). In the most valuable parts of her study she looks at some of the factors which influence the transposition of one literature into another literary system (Nikolajeva, 1996: 27, 30, 34-37). Her final judgment is:

The notion that there is a 'common' children's literature in all countries in the world is a misunderstanding. [...] although the general exchange of information in the world is growing, children's literature is becoming more and more national and isolated. Worldwide, the share of children's books occupied by translations is tending to decrease, and foreign books have great difficulties competing with national texts.

(Nikolajeva, 1996: 43)

(3) The difficulties of doing justice to a foreign culture and being politically correct within one's own culture (cf. Kullmann, 1994: 155)

In 1994 Jürgen Martini made a critical evaluation of recently published intercultural books about Africa for child and young adult readers (including picture books) by German and African writers and artists. He noted that the books addressing young adults were still characterised by a high amount of eurocentrism and racism, whereas the books addressing younger readers offered convincing alternatives (Martini, 1994: 96).

(4) The dichotomy between foreign language achievements and the developmental psychological characteristics of the respective age group and its thematic reading interests

Children's literature is a special case in point because we have to differentiate between native tongue achievements and foreign language skills in child or young adult readers. For example, at the time when German pupils are old enough to read and understand Alice's Adventures in Wonderland, The Hobbit or even Winnie-the-Pooh in the original they would 
almost certainly have lost any personal interest in the contents (cf. Tabbert, 1991: 176 on the issue of 'Stufung', adaptation etc).

\section{3 Suggestions}

In order to deal seriously and responsibly with the challenges of mediating foreign cultures to young people through children's books, i.e. to promote a truly intercultural communication, the following consciousness-raising measures are recommended for working with children's books from foreign backgrounds:

Creating an awareness of the intricate correlation between 'self' and 'other' in approaching a foreign culture

Taking a psychoanalytical approach, Jürgen Kramer, in an article in 1999, made it quite explicit that 'the other' (cultural alter ego) is not outside of us but rather inside of us. This implies

Eine fremde Kultur und Gesellschaft verstehen zu wollen, ohne das Fremde in uns in den Blick zu nehmen, ist daher stets zum Scheitern verurteilt. Nur auf dem Weg über das Fremde in uns - d.h. über die Analyse der Verfassung unserer Innen- und Außengrenzen und der (je individuellen) Verarbeitung der Eingliederung in die kulturelle Ordnung einerseits und die Herstellung von relativ flexiblen Bedingungen, die die nachträgliche Bearbeitung dieser Strukturen erlauben andererseits, - können wir uns dem Fremden außerhalb nähern.

(Kramer, 1999: 49)

(To attempt to understand a foreign culture and society without taking into account the foreign within ourselves is to condemn our endeavours to failure from that point on. Only by starting with the foreign in ourselves - and from there going on to an analysis of what constitutes our inner and outer boundaries (however individual), redefining our place in the cultural order on the one hand and restoring the relatively flexible conditions which allow additional reworking of these structures on the other - can we approach the foreign outside ourselves.)

(2) Developing an awareness of the process and dialogic character of intercultural teaching and learning

Lothar Bredella and Werner Delanoy (1999) put special emphasis on these characteristics of 'learning about a foreign culture' in their introduction to Interkultureller Fremdsprachenunterricht: 
Dabei ist zu bedenken, daß Selbst- und Fremdverstehen grundsätzlich unabschließbare Größen darstellen. [...] Dies ist auch der Grund, warum interkultureller Fremdsprachenunterricht nicht in der Vermittlung von Wissen über fremde Kulturen aufgeht, sondern den Lernenden im Unterricht Gelegenheit zum Aushandeln kultureller Bedeutungen geben muß.

$$
\text { (Bredella / Delanoy, 1999: 12-13) }
$$

(From this one could say that an understanding of self and an understanding of the foreign are fundamentally two inseparable dimensions. [...] This is also the reason that intercultural foreign language teaching is not defined by the transfer of knowledge about foreign cultures, but must be defined by the provision of opportunities in class to negotiate cultural meaning.)

Meeting the need for critical multiculturalism

According to Daniel D. Hade (1997) managed multiculturalism just celebrates cultural difference, fixes the boundaries between groups and leaves groups as they are constituted at present as givens. In children's literature this promotes the belief that the identity of the author matters in the authenticity of the story. Hade highlights the special need for critical multiculturalism which would make it possible to search for ways to affirm and celebrate difference while seeking ways to cooperate and collaborate across different groups of people (Hade, 1997: 115, 121)

(4) Developing a sensitive attitude towards presentations of 'the other' in children's literature

An important contribution has been made towards establishing how children's literature can help to create intercultural understanding by Hurrelmann and Richter (1998). One starting point for the project was obvious deficiencies in research (the need to see children's literature as a field of exchange between different cultures, to treat it interculturally, to undertake comparative studies). The other one was the issue of attitudes (the desirability of a fading out of cultural differences vs. the necessity of maintaining such differences). The most significant issues addressed in the volume are in fact the ways in which children's literature represents 'the other', how much space it allows indeed for otherness and intercultural communication. One important aspect that must not be neglected in this context is the role that adults play as 'gatekeepers' within the system of children's literature (Hurrelmann / Richter, 1998: 7-9).

Applying those kinds of criticism that allow for as broad as possible a range of approaches to the complex potential of children's literature

The application of reader-response theory or insights from semiotics seem to offer particular promise. Semiotics recognises the link between language and culture. The awareness that language is culturally patterned is a prerequisite for using children's literature for the purposes of promoting multiculturalism (Stephens in Hunt, 1996: 60)

(6) Selecting books appropriately (in the sense both of Hade (1997) (a balance of cultural difference and cooperation) and Nikolajeva (1996) (a balance of native and exotic elements; cf. also Bimberg: 2000)

(7) Creating opportunities for intercultural learning through picture books 
In America, Wilma Kuhlman and Mary J. Lickteig (1999), for example, have attempted to identify picture books that incorporate languages other than American English and found many books that provide opportunities for children to discover non-English words and learn something about the cultures from which these words originate. They have also done research on Japanese and Chinese books which include information on the languages themselves (Kuhlman / Lickteig, 1999: 93, 94).

Another important work is that of Heidi Rösch (1997). Bilderbücher zum interkulturellen Lernen combines a critical view on quite a number of children's books on or from other cultures available in German; recommendations for concrete work with them; and theoretical reflections on an intercultural and interlingual picture book didactics. The main concern is with intercultural work beginning in the primary school. It focuses on transcending the reception of text and pictures, encouraging discourse on interculturally relevant issues such as ethnocentrism, racism, nationalism etc. Rösch makes a special point of the fact that 'self' and 'other' is a central category within the intercultural didactics of foreign languages (Rösch, 1997: 199).

Creating cross-cultural experiences through the written and spoken word and folklore (use of methods of folklore studies)

Nina Jaffe (1999) explores a typical situation of shifting demographics in the U.S. where recently arrived immigrants live together with native speakers. She was intrigued by the challenge of reaching out and communicating with children of many different cultural and language backgrounds in her work as storyteller, educator and writer of books for young readers. She likes engagement with songs, rhymes, folktales, dance games and rhythms from different cultures ( Jaffe, 1999: 100). She regards these as

a language in themselves - creating a medium that all children, no matter what their ethnic heritage or cultural background, can connect to through physical, aesthetic, social and imaginative senses.

$$
\text { (Jaffe, 1999: 101) }
$$

\section{Using appropriate translations of children's literature}

Turgay Kurultay, in dealing with issues of- translating children's literature, criticises the general inadequacy of theory on the subject, though children's literature appears once more as a special range of experience with a paradigmatic role for translation theory in general. Applying the more recent approach of the communicative translation concept to children's literature translations, Kurultay emphasises two major aspects: the position and role of children in society and the reception conditions of the children that are particularly relevant not just in the monocultural communicative process but even more so in intercultural communication and the translation process. Translation can be a medium of intercultural communication (Kurultay, 1994: 191-3). According to Kurultay 'the other' in translated children's literature' has to be defined in a complex way, including at least attitudes and literary forms which may provide problems in the child's reception of them. Consequently, he attributes to the translator a very important communicative role (cf. Kramer, 1999). To be effective in the goal culture, a translation has to meet certain requirements: 
Die unerläßliche Voraussetzung dafür ist, daß der Übersetzer die Probleme der Kinderwelt und die Fragestellungen der $\mathrm{KL}$ kennt. Allgemein für die kinderliterarische Übersetzung kann man sagen, daß in der Übersetzung „mehr“ Anpassung an Kinder der Zielkultur (im Vergleich zu der Übersetzung der Erwachsenenliteratur) geboten ist, und dies muß nicht zuletzt im Interesse der adäquaten Übertragung des Originals geschehen. Das Problem für die Übersetzungstheorie liegt darin, inhaltliche Kriterien für dieses 'mehr'herauszustellen.

(Kurultay, $1994: 200$ )

(It is essential for the translator to know the problems of the children's world and the issues of children's literature. Generally, one could say of children's literature translation that, in the process of translation, 'more' adjustment to the goal-culture is called for than is necessary in translation of adult literature, and this must happen in the interests of an adequate rendering of the original. The problem for translation theory lies in defining this 'more'.)

\section{CONCLUSION}

Despite the difficulties of mediating a foreign culture/foreign cultures through children's literature, children's books can certainly make a distinctive contribution to promoting multilingualism and multiculturalism if certain prerequisites are met. Multiculturalism implies a critical attitude towards the workings of such issues as race, class, gender, power, status, and language in children's literature. Consequently, the approaches and methods employed must allow the creative use in the teaching of children's literature particularly of those kinds of literary criticism that make for open, critical and varied approaches. The responsible teaching of children's literature demands that the teaching staff do all they can to ensure that students or pupils play an active role in the reading process and in the sharing and communicating of mutual experiences of reading texts. Only if child and young adult readers experience the creative power of literature themselves, and voluntarily engage in personally meaningful reading will they be able to develop into active, critical and life-long readers in rapidly changing modern multicultural societies.

For these reasons, Peter Hunt envisages a new role for children's literature within Higher Education in the future:

An analysis of this situation [academia's still largely sceptical or hostile attitude to the subject of children's literature - C. B.] suggests that rather than being an anomalous subject, Children's Literature could provide a model for the development of higher education in the future, but to do so, it will have to circumvent conventional modes of academic thought.

(Hunt, 1995: 19) 


\section{REFERENCES}

BIMBERG, CHRISTIANE. 2000. Familie, Adoleszenz und Ethnizität in ausgewählten Jugendbüchern von Virginia Hamilton: Plädoyer für einen multi- und interkulturellen Verständigungsproze $\beta$, In Bimberg, C (Ed.) Perspektiven der englischsprachigen Kinder- und Jugendliteratur Bd. 3, Internationale Studien zu Literatur, Musik und Theater. Kamen, Vilnius, St. Petersburg, Thessaloniki, Moscow, Bejing, New York, Paris: Karthause-Schmülling Internationale Verlagsgesellschaft.

BIMBERG, CHRISTIANE. 1997. Shakespeare als Herausforderung an die fremdsprachige Lektüre von Anglistikstudenten. In Eicher, Thomas (Ed.), Zwischen Leseanimation und literarischer Sozialisation. Konzepte der Lese(r)förderung. Oberhausen: 159-90.

BIMBERG, CHRISTIANE. 1996. A German view of British classics and the need for an interdisciplinary discourse. Para •Doxa. Studies in World Literary Genres, 2(3-4):40610 .

BREDELLA, LOTHAR \& WERNER DELANOY (EDS). 1999. Interkultureller Fremdsprachenunterricht. Tübingen: Gunter Narr Verlag.

BRIGGS, JULIA. 1988. Awkward questions. Times Literary Supplement (1-7 April):372.

EWERS, H-H, U NASSEN, K RICHTER, \& R STEINLEINRÜDIGER (EDS). 1994. Kinderliteratur im interkulturellen Prozeß. Studien zur Allgemeinen und Vergleichenden Kinderliteraturwissenschaft. Stuttgart and Weimar: Verlag J. B. Metzler.

EWERS, H-H, U NASSEN, K RICHTER, \& R STEINLEINRÜDIGER (EDS). 1995. Kinder- und Jugendliteraturforschung 1994/95. Stuttgart and Weimar: Verlag J. B. Metzler.

EWERS, H-H, U NASSEN, K RICHTER, \& R STEINLEINRÜDIGER (EDS). 1997. Kinder- und Jugendliteraturforschung 1996/97. Stuttgart and Weimar: Verlag J. B. Metzler.

FLYNN, RICHARD. 1997. The intersection of children's literature and childhood studies. Children's Literature Association Quarterly, 22(3):143-45.

GASCHKE, SUSANNE. 1995. Die Welt in Büchern. In Böhm, Rudolf, Konrad Groß \& Dietrich Jäger (Eds), Kinder, Literatur und ästhetische Wirkung. (Kieler Beiträge zur Anglistik und Amerikanistik. Neue Folge Bd. 10). Würzburg: Könighausen \& Neumann.

HADE, DANIEL D. 1997. Reading children's literature multiculturally. In Beckett, Sandra L (Ed.), Reflections of change: Children's literature since 1945. Contributions to the Study of World Literature, Number 74. Greenwood Pr: 115-22.

HOLLINDALE, PETER. 1998. A place for children's literature in English Studies. The European English Messenger, 7(2): 40-43. 
HUNT, PETER. 1994. An introduction to children's literature. Oxford and New York: OUP. HUNT, PETER. 1995. Dragons in the department and academic emperors: Why universities are afraid of Children's Literature. Compar(a)ison, 2: 19-31.

HUNT, PETER (ED.) 1996. International Companion Encyclopedia of Children's Literature. London and New York: Routledge.

HURRELMANN, BETTINA AND KARIN RICHTER (EDS). 1998. Das Fremde in der Kinder- und Jugendliteratur. Interkulturelle Perspektiven. Weinheim and Munich: Juventa Verlag.

ILLNER, JAGODA AND EIKE THÜRMANN. 1999. Schulentwicklung und Schulprogramm. Erziehung zur Mehrsprachigkeit. Neue deutsche Schule, 51 (September):10-12.

JAFFE, NINA. 1999. Languages and the world of children's books. The Five Owls, 13(5):100-01.

KRAMER, JÜRGEN. 1999. Das Verstehen fremder Kulturen. Möglichkeiten und Grenzen aus ethnologischer, hermeneutischer und psychoanalytischer Sicht. In Lenz, Bernd \& Hans-Jürgen Lüsebrink (Eds), Fremdheitserfahrung und Fremdheitsdarstellung in okzidentalen Kulturen: Theorieansätze, Medien/Textsorten, Diskursformen. Passau: Wissenschaftsverlag Richard Rothe: 37-53.

KUHLMAN, WILMA AND MARY J LICKTEIG. 1999. Jambo, Hola, Konnichiwa: They all mean hello. Using picture books to introduce children to the languages of the world. The Five Owls, 13(5):93-94.

KUHLMAN, WILMA AND MARY J LICKTEIG. 1999. Languages of the world: A bibliography of picture books. The Five Owls, 13(5):95-99.

KULLMANN, THOMAS. 1995. Review of Martini (and Ewers 1994). In H-H Ewers et al. (eds), Kinder- und Jugendliteraturforschung 1994/95). Stuttgart and Weimar: Verlag J. B. Metzler:153-58.

KURULTAY, TURGAY. 1994. Probleme und Strategien bei der kinderliterarischen Übersetzung im Rahmen der interkulturellen Kommunikation. In Ewers, $\mathrm{H}-\mathrm{H}$ et al.: 191-201.

LESNIK-OBERSTEIN, KARIN. 1994. Children's literature. Criticism and the fictional child. Oxford: Clarendon Press.

MARTINI, JÜRGEN. 1994. Überall ist Afrika, oder: Das Eigene und das Fremde. In Ewers, H-H et al.: 92-96.

MAY, JILL P. 1995. Children's literature and critical theory. Reading and writing for understanding. New York and Oxford: Oxford University Press. 
NIKOLAJEVA, MARIA. 1996. Children's literature comes of age. Toward a new aesthetic. New York and London: Garland Publishing, Inc.

OSKAMP, I. M. 1996. Jugendliteratur im Lehrerurteil. Historische und didaktische Perspektiven. Würzburg: Königshausen und Neumann, (Schriftenreihe der Deutschen Akademie für Kinder- und Jugendliteratur Volkach e. V. 19).

O'SULLIVAN, EMER. 1997. Internationalität der Kinder- und Jugendliteratur zwischen Mythos und Realität. In Ewers, H.-H. et al. (eds): 86-104.

O'SULLIVAN, EMER. 1995. Neuere Ansätze in der englischsprachigen Kinderliteraturwissenschaft. In Ewers, HH et al. 1994/95: 95-110.

PETZOLD, DIETER. 1997. Anglistik und Kinderliteratur. Anglistik, 8. Jg. (1), March, 75-90.

RANK, BERNHARD. 1997. Review of Oskamp. In Ewers, H-H et al., Kinder- und Jugendliteraturforschung: 189-91.

RÖSCH, HEIDI. 1997. Bilderbücher zum interkulturellen Lernen. Hohengehren: Schneider Verlag.

ROSE, JACQUELINE. 1992. (1984). The case of Peter Pan or the impossibility of children's fiction. Revised Edition. London: Macmillan.

STEPHENS, JOHN. 1996. Linguistics and stylistics. In Hunt, P (ed.), International Companion Encyclopedia of Children's Literature. London and New York: Routledge:58-70.

TABBERT, REINBERT. 1991. Vom Nutzen der Kinderliteratur für den Fremdsprachenunterricht. In Winfred Kaminski (ed.) Kinderbuchanalysen II. (Jugend und Medien, Bd. 22). Frankfurt am Main: dipa-Verlag: 175-83.

\section{Biographical Note}

Christiane Bimberg is Professor of English Literature at the University of Dortmund / Germany. She has published widely in the fields of English Renaissance and Restoration Literature as well as British and American drama and theatre and children's literature of the 20th century. Her current research interests centre on interdisciplinary approaches and projects such as the musical, childhood and picture book studies, and intercultural relationships between English and Russian literature. 